\title{
"You can't be mad forever": Donald Marshall on Life After Prison
}

Thomas Mann

When I think back about the booze and dope, maybe in a strange way prison saved me. It preserved my body by putting me on the shelf for ten years or so. Many of my friends from the old days are now pushing up daisies or are "out to lunch" from the booze and dope. It could have been me.

Donald Marshall

$\mathrm{D}$ onald Marshall's soft-spoken and easy-going demeanor, combined with his boyish sense of humour and an uncomplicated view of the world, make one instantly at ease talking with him. Not often does he complain or criticize. He is from the old school. He calls it the way he sees it and without hesitation. He has slugged it out a time or two along the way. Sometimes he won, sometimes not. He rarely looks back into his past except when asked, which is far more frequent than he prefers. He generally accepts his "celebra-con" status, at times jokes about it, yet has a disdain for the media who created it.

"The media will eat you up and leave nothing. They can be brutal. They can turn you around so fast they will give you a hernia," states Marshall.

He is very committed to his family, his Native Micmac community, and friends. He warmly and frequently discusses his recently deceased father, former Micmac Grand Chief Donald Marshall Sr., as well as his work with native young offenders. Donald likes to laugh and enjoy life. His passion is fishing which he does regularly on the lake at the end of his road. Donald considers himself a "people-person."

"My place is busier than the local welfare office!" jokes Marshall.

He is the kind of guy who would give you "the shirt off his back," but on the other hand you would not want to be the target of his wrath. There is no doubt he handles problems head-on and with no mystery. He is no stranger to trouble, a fighter, and that is how he endured eleven years in prison for a murder he did not commit. 
On May 22, 1971, a friend of Donald's, 17 year old Alexander (Sandy) Seale was stabbed to death in Sydney, Nova Scotia's Wentworth Park. Within a week, Donald Marshall Jr. was charged with first-degree murder and held pending trial. Six months later, Donald was quickly convicted and sentenced to life imprisonment based on the questionable testimony of three teenage witnesses. On June 20,1972, at 17 years of age Donald Marshall, federal prisoner number 1997, entered Dorchester maximum security Penitentiary, one of Canada's five toughest prisons.

In recent years his name has been associated with "The Three M's" of Wrongful Conviction": Marshall, Morin, and Milgaard. They were all falsely charged, convicted, and incarcerated for murder and are symbols of failure of the Canadian criminal justice system. They were all falsely convicted, yet they coped with their individual circumstances very differently.

Guy Paul Morin spent over a decade in courtrooms, battling firstdegree murder charges surrounding the death of his neighbour Christine Jessop. After three trials, he was ultimately incarcerated in the gothic Kingston Penitentiary, which houses the most despised of Canada's federal prisoners. Sex offenders like Clifford Olsen and Paul Bernardo, as well as prisoners needing protective custody, have occupied this facility. Prisoners in other institutions refer to it as "The House of Shame."

The "Guy Paul Morin Inquiry" has put police and prosecution methods, tactics, and ethics under fire to the point of possible criminal prosecution. We have come to know through the media that the softspoken and articulate Guy Paul is a person of strong principles, faith and character. He has often stated, "I knew it was going to work out; it was just a matter of time." While incarcerated he busied himself with tailoring, tutoring, reading and his music. This past fall, Guy Paul received 1.5 million dollars as compensation for his wrongful conviction.

In 1997, David Milgaard captured headlines when he was fully exonerated by DNA evidence for the 1969 rape-murder of Saskatchewan nurse Gail Miller. Larry Fisher, who has served 23 years for a string of knife-point rapes, has now been charged with the murder. David spent 22 years in various federal institutions across Canada. In the harsh and 
insane prison environment there often is victimization. David was totally out of place in prison and this left him vulnerable. He was stabbed twice, had his leg broken, and was bludgeoned with a pipe during his incarceration. It has taken a heavy toll on David both physically and mentally, resulting in considerable enduring pain and anguish.

"I did 'time' with David in Dorchester Pen. He's been through a lot and is taking some pretty big steps. I hope he keeps it together and doesn't lose it. It's got to be hard, hard, hard after all those years," comments Marshall.

Guy Paul Morin, through his simple, yet deep faith, found his way through his strife and it looks as if he is well on his way to a relatively normal life. David Milgaard has many mental and physical scars to heal. He chose to face prison straight on and it overwhelmed him, but he survived and has another chance. Donald Marshall fought his way through prison using his wits and often his fists. He refused to be beaten and within the Maritime prison population, in the jargon, is a "respected con." Release meant freedom, but also many more court challenges for Donald, as well as the need to deal with some personal turmoil.

"It was wild getting out after many years. 'Inside' you get a routine going and once outside it's hard to undo. I've been out sixteen years now, and it's only been in the past six or seven I've gotten my life together. For years it was booze and dope every day."

Things were also hard for Donald growing up on the Membertou Reserve outside of Sydney, Nova Scotia. He was raised in a close, but very poor, family of thirteen children and became a hard-drinker at a young age. "When I was young we didn't have much, but I didn't want anything too special. All I needed to be happy was to hang out with my friends, a couple bottles of wine, some smokes, and my long, greasy-hair."

Donald is a proud native Micmac and scorns the prejudice he has experienced most of his life. "If I wasn't a Micmac probably they wouldn't have even charged me with the murder. The courts didn't want to give me a chance, and the cop who set me up hates Indians," Marshall recalls passionately. "Racism has improved considerably over the past ten years, but there still is extreme prejudice in our criminal justice system 
for natives, blacks and the poor. Courts aren't supposed to rule because of the colour of someone's skin. They assume you are guilty always before the courts if you're not white. Ten years ago you didn't have a chance at all. At least we can face the courts now."

The positive side to dealing with prejudice and the harsh streets as a youth is that it gave Donald the street sense to deal with the insane prison environment. Faced with life imprisonment he knew he had to endure and make things work for himself the best he could. It could not have been easy for a teenage youth.

"It's crazy in there. You see the hunger strikes, then the riots, then some stabbings. Eventually your life becomes a blur and much of what you used to think was crazy about prison you don't notice anymore. It's a whole different world. You relive your life. You go in young, stupid, naive, and come of age. Learn the rules and how things work. You get your routine and live your life. You've got to be strong and not allow anyone to push you around, but normally your just doing your time. Maybe then, if you're lucky, you get out. It's never the same for you, though. You never completely unchange."

After a couple of years Donald knew he had to get out of the brutal maximum security Dorchester "Pen," and work his way down to lower security level institutions. This would be necessary if he was ever to see an eventual release to a halfway house, or ultimately parole into the community. The difficulty was that he had to take full accountability for his crime and show remorse in order to be considered for a lower security facility. This would mean admitting guilt for a crime he did not commit: an action that could prove to be detrimental if his case were to be reopened.

Donald gambled and told correctional staff what they wanted to hear. Soon afterwards he was transferred to Springhill medium security, yet it was not all he planned. Many fights ensued and when the opportunity arose he escaped on a pass in October 1979. Two days later he was caught and returned to Dorchester. Now there was little chance of a release for a long, long time. 
Journal of Prisoners on Prisons, Vol. 9. No. 1, 1998

"What kept me going was my family. They'd scrape up whatever money they could and come up and see me two or three times a month. They couldn't stay in hotels, so they'd camp in their van. It made me strong knowing they were doing my time with me. I wasn't alone," reflects Marshall.

During a visit in August of 1981 with his girlfriend Shelly Saranson and her brother Mitchell, Donald was asked if he knew Roy Ebsary. He did not recall the name, but apparently the elderly, former psychiatric patient had been boasting he was the actual killer in Marshall's case. This discussion set the stage for "Junior's" eventual release and the truth becoming known, but it was not simple. Nothing happened quickly or easily. He was released on parole, on March 29, 1982, retried then acquitted in May of 1983. Then came the battle for compensation which ultimately paid Donald $\$ 270,000.00$, plus a monthly stipend in September of 1984.

Further court appearances involved the trial and conviction of Roy Ebsary for "Sandy" Seale's murder in 1985. Next was a Royal Commission, presided over by Newfoundland Supreme Court Judge Alexander Hickman, and mandated, "to make recommendations that will ensure that the unfortunate events surrounding Mr. Marshall will not be repeated." Finally, years of lengthy civil cases ensued in which Donald sought damages from the investigating police. He dropped all his suits, in the early nineties, in sheer frustration and exhaustion.

"I'd spent over twenty years in court and prison. After nine years in civil court and preparation to call over 130 witnesses, and the RCMP say I have no evidence, no case. Then my lawyer gets appointed to be a judge and I have to start all over with new counsel. Most of my witnesses were to discuss the wrongdoing of the police. They didn't want to give me a chance," recalls Marshall. "I knew at that point it was time to go on with life. Enough was enough. At least with Guy Paul Morin's and David Milgaard's cases, the police are admitting their wrong-doings. Still today, the Sydney Police maintain they did nothing inappropriate. Partially, they don't like me personally; as well, they just don't like natives, period.

"Occasionally I said to myself, jail was better for me than this crazy world. Life can be such a bitch out here at times. People on the street 
kick your dog, then steal your car, then mock you because they can hide behind the law for protection. Often the law itself is questionable, not to mention lawyers. There just is so little respect. Prison can be harsh and I certainly don't recommend it to anyone, but in many circumstances there is more fairness to prison justice. Cons, for the most part, treat each other fairly and protect and defend their values. Out here, often it's just nuts.

"I gave up on all my civil suits, but the Supreme Court of Canada recently accepted my appeal in a case questioning the fishing rights of Native Canadians. This is a native issue more so than a Donald Marshall issue. Somebody has to support the poor lawyers," adds Marshall with a chuckle.

After so many years in courtrooms and prison, one might suspect Marshall would want nothing to do with criminal issues. "If I was a preacher I'd read the bible. If you're an architect, you like to read blueprints. I'm an ex-con and I like to read, study, and be involved with prisons and prisoners." Concerns and interest with the justice system, as well as deep and strong native pride, has encouraged him to reach out to native young offenders. During the past three summers he has organized a summer camp. Donald is very dedicated to this project and the nonprofit foundation is named after his father.

"We take native kids out of the two Nova Scotia young offenders institutions," Mr. Marshall describes proudly. "Kids aged 10-17, who have all had problems with the law. Most are pretty good kids but come from broken homes and have trouble with dope and booze. We teach them to get along with each other and to feel some pride for themselves, to hold their heads high. The National Film Board made a movie about it last year that is being played on reserves throughout the country for crime prevention.

"The downside is money. We could have more kids involved if we had more funding. I'm going to the federal government for support this year. Another big disappointment are the parents. I invite the parents to come on the last day when we give out awards to the kids. We have trophies and plaques and some cash prizes to recognize positive participation. Many of the parents promise they'll come and then don't show up on this special day. How can they expect their kids to have 
personal pride, if they've never seen their own parents proud of them? It makes me furious. Next year I'm not asking the parents, I'm telling them to be there!

"Kids live in such a different world today. Nikes and Adidas, television and video-games, yet for many, no parents. So many wants and pressures, but no direction. Many don't have any life skills and discipline because they've never seen any at home. I try to tell judges to give the kids a break or two. If they've never had much of a life since day one, how can we expect them to get along outside of the home? If they get in trouble, send them to my camp or a Native Healing Circle. If they keep getting into mischief, then there's not much anyone can do. Maybe then they have to go down 'the hard-road.' Let's at least try other options first."

After most of Donald's late teens and twenties were lost in prison, his thirties in courtrooms and a haze of drugs and alcohol, one would expect some regrets. Also, with the notable financial settlement received by Guy Paul Morin, and a large compensation package being mentioned for David Milgaard, one would not be surprised if Donald Marshall would be somewhat bitter after his smaller financial contract with Nova Scotia.

When asked, he replied with a chuckle, "I'm out, I'm free, and I'm happy. I'm a fighter and I won. You can't be mad forever. I'm happy the boys are getting some money because they deserve it. Money for me is nothing. I'm not a money guy. Now I give it to Native charities, instead of bartenders!" 